\title{
Muzyka kościelna w archidiecezji krakowskiej w latach 1997-2017
}

\author{
ks. Robert Tyrała \\ Uniwersytet Papieski Jana Pawła II w Krakowie \\ robert.tyrala@upjp2.edu.pl (1) https://orcid.org/0000-0003-3659-4173
}

Sytuacja muzyki kościelnej w poszczególnych ośrodkach w Polsce i na świecie zależy od rozmaitych czynników. Z pewnością pierwsze z nich to czynniki ludzkie, bo albo duchowni i świeccy zainteresowani są tym problemem, albo niestety wcale ich nie interesuje właściwy poziom muzyki w liturgii. Kolejny czynnik wpływający na stan muzyki to stosunek do sprawy rządcy Kościoła, bowiem od biskupa diecezjalnego w tej kwestii bardzo wiele zależy. Sprzyjające też muszą być warunki ekonomiczne, które nie są bez znaczenia, gdyż inwestycja np. w edukację młodych organistów czy dyrygentów to działanie długofalowe i nie od razu widać jej efekty, a równocześnie jest ona bardzo kosztowna.

Przedstawione w niniejszym artykule wydarzenia i dokumenty dotyczące muzyki kościelnej obejmują ostatnie 20 lat (1997-2017), bowiem w tych latach autor artykułu wraz z prof. Józefem Serafinem, dr Mieczysławem Tuleją, ks. prof. Andrzejem Zającem, Jackiem Kuligiem, prof. Wiesławem Delimatem, dr hab. Witoldem Zalewskim, s. dr hab. Susi Ferfoglią, dr. Krzysztofem Michałkiem, ks. dr. Wojciechem Kałamarzem CM, o. dr. Dawidem Kuszem OP, prof. Włodzimierzem Siedlikiem, prof. Jerzym Kurczem, Markiem Walczakiem, Tomaszem Kucem i wieloma innymi zajmowali się muzyką kościelną w archidiecezji krakowskiej. Trzeba też podkreślić, iż czas ten za rządów kard. Franciszka Macharskiego oraz kard. Stanisława Dziwisza był dla środowiska muzycznego w archidiecezji krakowskiej bardzo owocny i dzisiaj odczuwamy pozytywne skutki podjętych w tym okresie decyzji, a wcześniej także przez kard. Karola Wojtyłę, jego poprzedników oraz ich duchownych i świeckich współpracowników. Należy się im prawdziwy szacunek i wdzięczność za położenie właściwych fundamentów, na których mogliśmy budować. Wymienić tutaj trzeba takie osoby jak ks. Jacek Żurek, doc. Marian Machura, Irena Pfeiffer, Alojzy Poziorski, Bogusław Grzybek, dr Jan Rybarski czy prof. Jan Jargoń oraz wielu innych. 
Zostaną tutaj przedstawione kolejno regulacje prawne dotyczące pracy organistów oraz troska o organy piszczałkowe i działania na rzecz chórów kościelnych, inicjatywy edukacyjne, a więc szkoły muzyczne dla organistów I i II stopnia na prawach państwowych oraz Międzyuczelniany Instytut Muzyki Kościelnej. W tym opracowaniu nie można pominąć także troski o formację duchową i rozwój zawodowy organistów. Ważne są także przygotowania muzyczne papieskich pielgrzymek $(1997,1999,2002,2006)$ oraz Światowych Dni Młodzieży (2016). Trzeba tutaj także przywołać wiele innych działań członków Archidiecezjalnej Komisji Muzyki Kościelnej w Krakowie, a zwłaszcza współpracujących z nimi instytucji kultury i edukacji muzycznej w Krakowie i archidiecezji.

\section{Regulacje prawne dotyczące pracy organistów}

W latach 1997-2000 Archidiecezjalna Komisja Muzyki Kościelnej wraz z wieloma organistami diecezji pracowała nad nową wersją regulaminu dla organistów. Ostatecznie 28 października 2000 roku kard. Franciszek Macharski podpisał regulamin, który miał obowiązywać przez pięć lat ${ }^{1}$. Bp Kazimierz Nycz, ówczesny wikariusz generalny metropolity krakowskiego, we wprowadzeniu do drukowanej wersji regulaminu pisał: „regulamin jest nowym narzędziem w ręku księży, organistów i organistek. Jeśli pomoże w rozwiązaniu spraw zatrudnienia, wynagrodzenia, a nade wszystko w pełnieniu pięknej misji służenia liturgii, to spełni swą rolę"2. Regulamin został podzielony na działy: władze organistowskie, cele i zadania podkomisji ds. organistowskich, charakter prawny stanowiska organisty, podział stanowisk i wymagane kwalifikacje, objęcie stanowiska, umowa o pracę, obowiązki organisty, uposażenie organisty, ubezpieczenie i emerytura, prawo do urlopu, rozwiązanie stosunku służbowego, przepisy końcowe. Załączony został także wzór umowy o pracę.

Kolejny regulamin dla organistów został ogłoszony w archidiecezji krakowskiej 22 listopada 2005 roku we wspomnienie św. Cecylii, patronki muzyki kościelnej, przez arcybiskupa Stanisława Dziwisza, metropolitę krakowskiego ${ }^{3}$.

1 Zob. Regulamin organistów Archidiecezji Krakowskiej, Kraków 2000.

2 K. Nycz, Wprowadzenie, [w:] Regulamin organistów Archidiecezji Krakowskiej, Kraków 2000, s. 2.

3 Zob. Regulamin organistów Archidiecezji Krakowskiej, Kraków 2005. 
Był on poprawioną wersją poprzedniego regulaminu i kolejną próbą systematyzowania spraw organistowskich w archidiecezji krakowskiej.

W 2011 roku ukazał się najnowszy i obowiązujący obecnie regulamin organistów archidiecezji krakowskiej ${ }^{4}$, który jest efektem pracy organistów i duchownych, prawników cywilnych i kościelnych ${ }^{5}$. Kard. Stanisław Dziwisz, metropolita krakowski, podpisał ten regulamin 23 czerwca 2011 roku w uroczystość Bożego Ciała ${ }^{6}$. Sam też we wstępie do tego dokumentu napisał: „Dziękuję, że zapowiadany przeze mnie w liście do organistów w listopadzie 2010 roku dokument został ukończony i dzisiaj ukazuje się z mocą obowiązującą dla tej cząstki Kościoła, jaką jest archidiecezja krakowska. Proszę, byście wszyscy konsekwentnie zrealizowali jego zawartość. Niezmiernie istotne jest jasne ukształtowanie dobrej współpracy pomiędzy księżmi a organistami. Bardzo ważne, by ta relacja była oparta na sprawiedliwości społecznej i na przejrzystości, także finansowej. Tylko w ten właśnie sposób będziemy wierni ideałom Założyciela Kościoła. Temu służy ten właśnie dokument”7. Zawiera on następujące rozdziały: przepisy wstępne, Komisja Muzyki Kościelnej, podział stanowisk i wymagane kwalifikacje, uzupełnienie wykształcenia organisty, objęcie stanowiska, obowiązki organisty, wynagrodzenie, ofiary otrzymywane od wiernych i inne świadczenia, formy zatrudnienia organistów, zatrudnienie na podstawie umowy o pracę, ubezpieczenia i emerytura, nagrody i odprawy, prawo do urlopu, rozwiązanie umowy o pracę, zatrudnienie na podstawie umowy zlecenia, wolontariat, dane osobowe, przepisy końcowe. Zawiera także załącznik nr 1, w którym określono czas pracy organisty oraz jego wynagrodzenie. Regulamin zawiera także 12 rodzajów umów i skład aktualnej Komisji Muzyki Kościelnej oraz dane teleadresowe Szkoły Muzycznej I i II stopnia oraz Międzyuczelnianego Instytutu Muzyki Kościelnej.

Regulamin ciągle wprowadzany jest w życie. Nie jest to łatwe zadanie, bowiem pracodawcy nie zawsze chcą zawierać umowy o pracę lub cywilnoprawne, a i pracownicy też od tego niejednokrotnie stronią. Do lutego 2017 roku sprawdzono pod względem zawarcia umów pomiędzy organistą

4 Zob. Regulamin organistów Archidiecezji Krakowskiej, Kraków 2011.

5 Zob. R. Tyrała, Regulamin organistów Archidiecezji Krakowskiej, Kraków 2011; R. Tyrała, Regulamin organistów w archidiecezji krakowskiej, „Pro Musica Sacra” 10 (2012), s. 9-20, https:// doi.org/10.15633/pms.336.

6 Tamże.

7 Tamże, s. 3. 
a parafią 416 parafii archidiecezji krakowskiej i odnotowano 121 umów o pracę (30 proc.), 110 wolontariatów (27 proc.), kolejne 12 proc. to porozumienia, umowy o dzieło oraz zlecenia. Do skontrolowania pozostało 127 parafii (31 proc.). Regulamin stał się więc w większości parafii dobrym narzędziem właściwej współpracy pomiędzy duchownymi a organistami.

\section{Regulacje prawne dotyczące organów piszczałkowych}

Wiele lat trwało przygotowanie i konsultacja treści regulaminu budowy organów, przeprowadzania remontów i renowacji oraz sprowadzania używanych organów w archidiecezji krakowskiej ${ }^{8}$. Właściwie prawie dziesięć lat (1997-2007) trwała dyskusja na posiedzeniach Archidiecezjalnej Komisji Muzyki Kościelnej w Krakowie na ten temat. Ostatecznie 18 marca 2007 roku w IV niedzielę wielkiego postu (laetare) kard. Stanisław Dziwisz podpisał ów dokument, przypominając, że jest to efekt pracy duszpasterzy i specjalistów w dziedzinie muzyki kościelnej w Krakowie. Metropolita krakowski we wprowadzeniu do regulaminu pisał: „ciągle trzeba o niego [instrument] dbać, gdy zachodzi potrzeba, należy dokonywać koniecznych remontów oraz prac renowacyjnych. Tam, gdzie to zaś możliwe i wspólnota Kościoła parafialnego może pozwolić sobie na sfinansowanie nowego lub używanego instrumentu, co jest także wyrazem troski o piękno i jakość kultu Bożego w naszych świątyniach, niech nie braknie nam odwagi oraz determinacji do realizacji tego zamierzenia. Proszę, przyjmijcie ten regulamin z wielką życzliwością i odpowiedzialnością zarazem. Godność spraw, w jakich uczestniczymy, a więc świętość, mobilizuje nas także do tego, by przygotowanie do nich było jak najbardziej doskonałe"9.

Regulamin podzielony jest na następujące działy: zasady ogólne, budowa nowych organów, przebudowa i remont istniejących organów, przeniesienie organów, odbiór techniczny organów oraz postanowienia końco$\mathrm{we}^{10}$. Założenie, iż prace przy instrumentarium w kościołach archidiecezji,

8 Zob. Regulamin budowy organów, przeprowadzania remontów i renowacji oraz sprowadzania używanych organów w archidiecezji krakowskiej, Kraków 2007.

9 S. Dziwisz, Stowo wstępne, [w:] Regulamin budowy organów, przeprowadzania remontów i renowacji oraz sprowadzania używanych organów w archidiecezji krakowskiej, Kraków 2007, s. 3-4.

10 Zob. R. Tyrała, Regulamin budowy, remontu i sprowadzania z zagranicy instrumentó $w$ w archidiecezji krakowskiej z 2007 r., „Musica Ecclesiastica” 11 (2016), s. 77-83. 
a także sprawy budowy czy renowacji lub sprowadzania z zagranicy wymagają zgłoszenia do Komisji Muzyki Kościelnej w zasadzie dobrze funkcjonuje. Są oczywiście wyjątki parafii czy rektoratów (najczęściej są to obiekty klasztorne), gdzie ich zarządcy podejmują te inicjatywy na własną rękę, co niestety niejednokrotnie źle się kończy. Niewłaściwie przeprowadzony odbiór prac czy niekompetentni wykonawcy to częste powody unieruchomienia cennych instrumentów na wiele lat. W Archidiecezjalnej Komisji Muzyki Kościelnej w Krakowie zasiadają obecnie znawcy budowy i remontu organów, dzięki czemu proboszczowie zwracający się do komisji z prośba o pomoc mogą liczyć na to, że będzie ona fachowa i merytorycznie poprawna.

Nie we wszystkich kościołach archidiecezji krakowskiej mamy jeszcze do czynienia z organami piszczałkowymi, ale blisko 300 kościołów może poszczycić się takim instrumentem. Wprowadzony w 2011 roku regulamin organistów archidiecezji krakowskiej ${ }^{11} \mathrm{w}$ paragrafie dotyczącym wizytacji muzycznej w parafii określa także konieczność sprawdzenia stanu technicznego instrumentu ${ }^{12}$. Zapis ten otwiera możliwości udzielania szerszej pomocy poszczególnym parafiom i ośrodkom duszpasterskim. Z tego już wielokrotnie skorzystaliśmy w sytuacjach nieco skomplikowanych.

W latach 1997-2017 wybudowano w archidiecezji krakowskiej 15 nowych instrumentów (parafia Najświętszego Salwatora w Krakowie, parafia św. Jana Kantego w Krakowie, parafia w Rzeszotarach, parafia w Bolechowicach, parafia Miłosierdzia Bożego w Skawinie, parafia Ofiarowania Najświętszej Maryi Panny w Wadowicach, parafia Wszystkich Świętych w Krakowie-Górce Kościelnickiej, parafia Świętego Krzyża w Zakopanem, parafia w Trzemeśni, parafia Miłosierdzia Bożego w Krakowie na os. Oficerskim, parafia Świętego Krzyża w Krakowie, Sanktuarium św. Jana Pawła II w Krakowie, parafia Matki Bożej Ostrobramskiej w Krakowie-Wieczystej, parafia Świętych Apostołów Szymona i Judy Tadeusza w Skawinie), w trakcie budowy nowego instrumentu są 3 świątynie: bazylika Miłosierdzia Bożego w Krakowie, bazylika Mariacka w Krakowie, parafia Zesłania Ducha Świętego w Krakowie na os. Ruczaj ${ }^{13}$. Z zagranicy sprowadzono 24 instrumenty (parafia św. Stanisława

11 Zob. Regulamin organistów archidiecezji krakowskiej, Kraków 2011; R. Tyrała, Regulamin organistów $w$ archidiecezji krakowskiej, dz. cyt.

12 Zob. Regulamin organistów archidiecezji krakowskiej, Kraków 2011, § 4, 2-3.

13 Zob. R. Tyrała, Regulamin budowy, remontu i sprowadzania z zagranicy instrumentów $w$ archidiecezji krakowskiej z 2007 r., dz. cyt. 
BM w Krakowie-Dąbiu, parafia św. Jana Chrzciciela w Krakowie-Prądniku Czerwonym, parafia Najświętszej Maryi Panny Matki Kościoła w KrakowiePrądniku Białym, parafia Matki Boskiej Częstochowskiej w Krakowie-Szklanych Domach, parafia Podwyższenia Krzyża Świętego w Krakowie-Kurdwanowie, parafia Najświętszej Rodziny w Krakowie-Bieżanowie, kaplica Wyższego Seminarium Duchownego Archidiecezji Krakowskiej, parafia w Naprawie, parafia w Gronkowie, parafia w Niegowici, parafia w Witanowicach, parafia św. Jana Pawła II w Nowym Targu, parafia w Brzeźnicy, parafia w Jaśkowicach, parafia św. Brata Alberta w Myślenicach, parafia św. Antoniego w KrakowieBronowicach, parafia w św. Stanisława BM w Krakowie-Toniach, parafia św. Barbary w Libiążu, parafia w Tenczynku, parafia w Leńczach, parafia bł. Anieli Salawy w Krakowie, parafia Matki Bożej Nieustającej Pomocy w Krakowie-Mydlnikach, parafia w Czernichowie, parafia w Mogilanach). $\mathrm{W}$ trakcie procedury sprowadzania instrumentu są 2 świątynie (bazylika w Ludźmierzu, parafia św. Józefa w Krakowie na os. Kalinowym). Dokonano remontu i renowacji 46 instrumentów w 45 świątyniach (parafia w Groniu, parafia Matki Bożej Nieustającej Pomocy w Krakowie-Podgórzu, parafia św. Józefa w Krakowie-Podgórzu, parafia św. Kazimierza w Krakowie, parafia w Podstolicach, parafia św. Klemensa w Wieliczce, parafia Matki Boskiej Zwycięskiej w Krakowie-Borku Fałęckim, parafia w Piekielniku, parafia św. Marii Magdaleny w Rabce, parafia Najświętszego Serca Pana Jezusa w Nowym Targu, parafia w Ludźmierzu, parafia w ChrzanowieKościelcu, parafia św. Mikołaja w Chrzanowie, parafia w Zabierzowie, parafia w Odrowążu Podhalańskim, bazylika Paulinów Na Skałce w Krakowie, bazylika św. Floriana w Krakowie, kościół Kapucynów w Krakowie, kościół Bernardynów w Krakowie, parafia w Brodach, parafia w Frydrychowicach, parafia w Zatorze, parafia Najświętszej Maryi Panny z Lourdes w Krakowie, parafia św. Szczepana w Krakowie, parafia Świętych Apostołów Szymona i Judy Tadeusza w Skawinie, parafia Narodzenia Najświętszej Maryi Panny w Myślenicach, parafia w Dobczycach, kaplica seminaryjna w Stadnikach, parafia Najświętszego Serca Pana Jezusa w Krakowie-Płaszowie, bazylika Najświętszego Serca Pana Jezusa w Krakowie, kościół św. Barbary w Krakowie, bazylika Mariacka w Krakowie (dwa boczne instrumenty), parafia św. Mikołaja w Krakowie, kościół św. Marka w Krakowie, kościół Karmelitów Na Piasku w Krakowie, parafia św. Katarzyny w Nowym Targu, parafia w Gdowie, parafia w Pcimiu, parafia w Igołomii, parafia w Łętowni, parafia w Waksmundzie, parafia w Czulicach, parafia w Miętustwie, parafia w Biskupicach, parafia 
św. Marii Magdaleny w Krakowie-Witkowicach) ${ }^{14}$. Łącznie nadzorem komisji zostały objęte zmiany instrumentów muzycznych w 89 obiektach sakralnych. Członkowie Archidiecezjalnej Komisji Muzyki Kościelnej prowadzą też konsultacje z duchownymi i organistami, które pomagają w zachowaniu powierzonych ich opiece organów piszczałkowych dobrym stanie.

\section{Chóry kościelne}

W omawianym czasie Archidiecezjalna Komisja Muzyki Kościelnej swoim patronatem objęła konkursy chóralne: Myślenicki Festiwal Pieśni Chóralnej Kolędy i Pastorałki oraz Ogólnopolski Konkurs Chórów o Złotą Strunę w Niepołomicach. Ponadto przez wiele lat z inspiracji członków komisji odbywał się konkurs chóralny Cantate Domino (uwzględniający kategorię chóry parafialne).

Członkowie komisji byli organizatorami Kongresu Polskiej Federacji Pueri Cantores w roku 2000 pod hasłem Jubilate Deo z udziałem tysiąca uczestników z całej Polski, a także XXXIV Międzynarodowego Kongresu Pueri Cantores w 2007 roku pod hasłem Misericordias Domini in aeternum cantabo z udziałem przeszło 3 tys. chórzystów z 18 krajów świata.

Z okazji międzynarodowego kongresu w 2007 roku we wszystkich kościołach archidiecezji odczytany został w niedzielę poprzedzającą kongres list metropolity krakowskiego o znaczeniu muzyki kościelnej w życiu Kościoła. Kardynał pisał w nim: „jednym z założeń federacji chórów Pueri Cantores jest edukacja młodych przez muzykę i liturgię. Jest więc rozwijanie się duchowe oraz artystyczne. Edukacja poprzez dobrą muzykę dotyczy Kościoła, tak samo jak dbałość o duchowy rozwój uczestników liturgicznych celebracji. Kształcenie i dokształcanie organistów, zakładanie i popieranie chórów kościelnych oraz schól liturgicznych, a także kształtowanie wspólnotowych śpiewów w naszych parafiach jest wyzwaniem chwili. To dotoczy rozwoju talentu ducha. Kościół bowiem był w historii i jest nadal strażnikiem dobrej muzyki. Koniecznie więc musimy o tym pamiętać. To są misja i zadanie, które dotyczą nas wszystkich"15.

14 Dane na ten temat są przechowywane w teczkach parafii archidiecezji krakowskiej przez Archiwum Archidiecezjalnej Komisji Muzyki Kościelnej w Krakowie.

15 S. Dziwisz, List pasterski do archidiecezji krakowskiej, 8 lipca 2007. 
Na terenie archidiecezji obecnie działa przeszło 100 chórów oraz schól parafialnych na stałe związanych z kościołami. W Krakowie ma swoją siedzibę Polska Federacja Pueri Cantores.

\section{Edukacja organistów i dyrygentów chóralnych}

Początki kształcenia organistów w archidiecezji krakowskiej sięgają pierwszych lat po II wojnie światowej - wówczas było osobne studium dla mężczyzn i osobne dla zakonnic. W ramach Instytutu Liturgicznego od 1974 roku odbywało się trzystopniowe kształcenie organistów, które stworzył doc. Marian Machura. Zorganizowane na poziomie akademickim kształcenie muzyków kościelnych odbywa się od 1981 roku w Papieskiej Akademii Teologicznej w Krakowie oraz od 1997 roku w Akademii Muzycznej w Krakowie na specjalności muzyka kościelna.

\subsection{Archidiecezjalna Szkoła Muzyczna I i II stopnia im. kard. Franciszka Macharskiego w Krakowie ${ }^{16}$}

Po wielu latach współistnienia studium organistowskiego w ramach Papieskiej Akademii Teologicznej w Krakowie, biorąc pod uwagę nowe warunki społeczno-polityczne w 1997 roku, kard. Franciszek Macharski powołał samodzielne studium dla organistów podlegające bezpośrednio biskupowi ${ }^{17}$. Konsekwentnie zaś rok później swoim dekretem przekształcił studium dla organistów w Archidiecezjalną Szkołę Organistowską. Jak zapisał w dekrecie powołującym szkołę: „mając na uwadze potrzebę pełniejszego uczestnictwa ludu wiernego w liturgii, ustanawiam z dniem 1 sierpnia 1998 roku Archidiecezjalną Szkołę Organistowską. [...] celem szkoły jest wszechstronne przygotowanie muzyczne kandydatów do sprawowania funkcji organisty

16 Zob. R. Tyrała, Historia kształcenia $w$ zakresie muzyki kościelnej $w$ archidiecezji krakowskiej po reformie soborowej, „Ateneum Kapłańskie” 153 (2009) nr 1-2 (599-600), s. 38-54; Ł. Sandera, Archidiecezjalna Szkoła Muzyczna imienia ks. kardynała Franciszka Macharskiego w Krakowie - historia i teraźniejszość, Akademia Muzyczna w Krakowie Międzyuczelniany Instytut Muzyki Kościelnej, Kraków 2015 (mps).

17 Zob. kard. Franciszek Macharski, Dekret ustanawiający Archidiecezjalne Studium Organistowskie, Kraków, 1 października 1997, Archiwum Kurii Metropolitalnej w Krakowie, NDz. 2885/1997. 
kościelnego i ich formacja duchowa”18. Szkoła ta 16 września 1999 roku uzyskała uprawnienia szkoły publicznej ${ }^{19}$ - stała się szkołą muzyczną II stopnia. Uczniowie kształcą się w niej przez 6 lat ${ }^{20}$, pobierając naukę w zakresie harmonii, zasad muzyki, historii muzyki, liturgiki, emisji głosu, praktyki liturgicznej, chorału gregoriańskiego, grając na fortepianie i organach. Obowiązkowo śpiewają w chórze szkolnym oraz scholi gregoriańskiej. Ukończenie szkoły organistowskiej - co jest równoznaczne z uzyskaniem średniego wykształcenia muzycznego - upoważnia każdego absolwenta do podjęcia dalszego kształcenia na uczelni muzycznej. W archidiecezji krakowskiej szkoła ta jest podstawowym miejscem kształcenia organistów, po ukończeniu której można się ubiegać o przyjęcie do pracy organisty w archidiecezji ${ }^{21}$. Arcybiskup krakowski każdorazowo (na 5 lat) mianuje dyrektora szkoły i sprawuje patronat nad szkołą. Od początku dyrektorem szkoły jest prof. Wiesław Delimat.

4 marca 2006 roku kard. Stanisław Dziwisz, „mając na uwadze dostosowanie istniejących struktur do nowych uwarunkowań prawnych” dokonał „zmiany nazwy Archidiecezjalnej Szkoły Organistowskiej. Nowa nazwa szkoły brzmi: Archidiecezjalna Szkoła Muzyczna I i II stopnia”22. Powołał tym samym dekretem szkołę muzyczną I stopnia. W listopadzie 2006 roku uroczyście zostało nadane jej imię kard. Franciszka Macharskiego, wielkiego przyjaciela i dobroczyńczy muzyki kościelnej. 31 stycznia 2007 roku Archidiecezjalna Szkoła Muzyczna I stopnia uzyskała uprawnienia szkoły publicznej ${ }^{23}$.

W latach 1997-2017 roku Archidiecezjalną Szkołę Muzyczną I i II stopnia ukończyło 209 uczniów. Obecnie w szkole pracuje 48 nauczycieli i kształci się 191 uczniów.

18 Zob. kard. Franciszek Macharski, Dekret ustanawiający Archidiecezjalną Szkołę Organistowską, Kraków, 30 lipca 1998, Archiwum Kurii Metropolitalnej w Krakowie, NDz. 2096/1998.

19 Zob. Decyzja Podsekretarza Stanu w Ministerstwie Kultury i Sztuki nadania Archidiecezjalnej Szkole Organistowskiej uprawnień szkoły publicznej, 16 września 1999, DSA.I.7755-ps21/A/99.

20 Zob. Ł. Sandera, Archidiecezjalna Szkoła Muzyczna imienia ks. kardynała Franciszka Macharskiego w Krakowie - historia i teraźniejszość, dz. cyt., s. 15-16.

21 Zob. W. Delimat, Archidiecezjalna Szkoła Organistowska, „Organista” 2000 nr 15, s. 2-3.

22 Zob. kard. Stanisław Dziwisz, Dekret dotyczący Archidiecezjalnej Szkoły Muzycznej I i II stopnia, 4 marca 2006, Kancelaria Metropolity Krakowskiego, NDz. 625/2006.

23 Zob. Minister Kultury i Dziedzictwa Narodowego, Decyzja w sprawie nadania uprawnień szkoły publicznej dla Archidiecezjalnej Szkoły Muzycznej I stopnia w Krakowie, 31 stycznia 2007, DSA II 077/383/2007/IS. 


\subsection{Międzyuczelniany Instytut Muzyki Kościelnej w Krakowie ${ }^{24}$}

Konieczność powołania kierunku muzyka kościelna (w Akademii Muzycznej w Krakowie kształcono na specjalności muzyka kościelna od 1997 roku; w Instytucie Liturgicznym w Krakowie od 1974 roku na specjalności muzyka liturgiczna) z możliwością nadawania stopnia magistra muzyki kościelnej towarzyszyła odpowiedzialnym za muzykę w archidiecezji krakowskiej od samego początku. Od przeniesienia Sekcji Muzyki Liturgicznej na Wydział Historii Kościoła, a tym samym stworzenia specjalności muzyka, czyli od 1999 roku prace te zostały bardzo zintensyfikowane. 19 marca 2001 roku senat Papieskiej Akademii Teologicznej w Krakowie postanowił, że studia z muzyki od nowego roku akademickiego rozpoczną się na Wydziale Historii Kościoła. Taka też struktura studiów, z uwzględnieniem minimum programowego z historii, obowiązywała od roku akademickiego 2001/2002 ${ }^{25}$. Ostatecznie nową specjalność muzyka powołano uchwałą senatu Papieskiej Akademii Teologicznej w Krakowie w dniu 10 grudnia 2001 roku. W 2002 roku powołana została Katedra Muzyki Kościelnej. Przez blisko cztery lata przygotowywany był projekt stworzenia kierunku muzyka kościelna. Od 2006 roku prace te nabrały nowego kształtu, gdy rektorzy Akademii Muzycznej w Krakowie i Papieskiej Akademii Teologicznej w Krakowie utworzyli komisję, która stworzyła dokumentację kierunku. Pod koniec 2007 roku dokumenty zostały złożone w Ministerstwie Nauki i Szkolnictwa Wyższego. 1 lutego 2008 roku nowy kierunek muzyka kościelna został zatwierdzony przez Ministra Nauki i Szkolnictwa Wyższego ${ }^{26}$ jako jedyna taka forma kształcenia muzyków kościelnych na poziomie licencjatu i magisterium. Uprawnienia zostały nadane dwóm współpracującym uczelniom, a więc Wydziałowi Historii Kościoła (dziś Historii i Dziedzictwa Kulturowego) Papieskiej Akademii Teologicznej w Krakowie (dziś Uniwersytetu Papieskiego Jana Pawła II w Krakowie) oraz

24 Zob. R. Tyrała, Kierunek „muzyka kościelna” nowa forma kształcenia muzycznego w Polsce, „Muzyk Kościelny” 2009 nr 1, s. 35-41.

25 Zob. Papieska Akademia Teologiczna w Krakowie Wydział Historii Kościoła, Informator na rok akademicki 2001/2002, Kraków 2001, s. 15-16.

26 Zob. Minister Nauki i Szkolnictwa Wyższego, Decyzja nadająca Wydziałowi Historii Kościoła Papieskiej Akademii Teologicznej w Krakowie uprawnienia do prowadzenia studiów na kierunku „muzyka kościelna”, 1 lutego 2008, DSW-1-03-4002/14/08; Minister Nauki i Szkolnictwa Wyższego, Decyzja nadająca Wydziałowi Twórczości, Interpretacji i Edukacji Muzycznej Akademii Muzycznej w Krakowie uprawnienia do prowadzenia studiów na kierunku „muzyka kościelna”, 1 lutego 2008, DSW-1-03-4002/15/08. 
dla Wydziałowi Twórczości, Interpretacji i Edukacji Muzycznej Akademii Muzycznej w Krakowie. Te uczelnie w 2008 roku utworzyły Międzyuczelniany Instytut Muzyki Kościelnej w Krakowie ${ }^{27}$.

Program nauczania studiów pierwszego stopnia obejmuje zajęcia $\mathrm{z}$ fortepianu (2 lata), dyrygentury, dyrygowania (3 lata), czytanie partytur (1 rok) i organów (3 lata) - powinny być prowadzone w trybie indywidualnym, natomiast z zakresu akompaniamentu liturgicznego (3 lata) - w trybie indywidualnym lub grupach 2-osobowych. Zajęcia z zakresu harmonii (3 lata), historii muzyki (3 lata), analizy dzieła muzycznego (2 lata), kształcenia słuchu (2 lata), kontrapunktu (1 rok), teorii, historii, paleografii i semiologii chorału gregoriańskiego (2 lata), chóru, scholi gregoriańskiej (3 lata), teologii muzyki (1 rok), propedeutyki teologii (1 rok), prawodawstwa muzyki liturgicznej (1 rok), liturgiki (1 rok), historii muzyki organowej (1 rok) i organoznawstwa (1 rok) są prowadzone zbiorowo. Przez trzy lata student pobiera naukę z emisji głosu (indywidualnie i zbiorowo). Z cyklem studiów pierwszego stopnia związane są praktyki (80 godz. z prowadzenia chóru oraz organów). Studia kończą się uzyskaniem dyplomu licencjata na kierunku muzyka kościelna po uzyskaniu absolutorium z trzech lat studiów oraz obronieniu pracy licencjackiej. Wówczas też absolwent może zdawać egzamin na dwuletnie studia uzupełniające magisterskie na kierunku muzyka kościelna. Studia drugiego stopnia trwają nie krócej niż 4 semestry. Liczba godzin zajęć nie może być mniejsza niż 800. Liczba punktów ECTS nie może być mniejsza niż $120^{28}$. W przygotowanym na podstawie standardów kształcenia na kierunku muzyka kościelna programie studiów na studiach drugiego stopnia łączna ilość treści podstawowych, kierunkowych i innych wynosi 900 godzin w ciągu dwóch lat.

Od roku akademickiego 2009/2010 ma miejsce kształcenie na kierunku muzyka kościelna w ramach Międzyuczelnianego Instytutu Muzyki Kościelnej w Krakowie. Do zakończenia roku akademickiego 2015/2016 roku studia ukończyło 38 absolwentów na poziomie licencjatu i 30 na poziomie magisterium. Pierwszym dyrektorem w latach 2008-2016 był ks. dr hab. Robert Tyrała. Od roku akademickiego 2016/2017 jest nim dr hab. Witold Zalewski.

27 Senat Papieskiej Akademii Teologicznej powołał Międzyuczelniany Instytut Muzyki Kościelnej na swoim posiedzeniu 17 listopada 2008 roku. Senat Akademii Muzycznej w Krakowie powołał Międzyuczelniany Instytut Muzyki Kościelnej na swoim posiedzeniu 29 września 2009 roku.

28 Zob. Standardy kształcenia na kierunku muzyka kościelna określone w decyzjach Ministra Nauki i Szkolnictwa Wyższego nr DSW-1-03-4002/14/08 i DSW-1-03-4002/15/08 z dnia 1 lutego 2008 r. 
W roku akademickim 2016/2017 Międzyuczelniany Instytut Muzyki Kościelnej w Krakowie w związku z osiągnięciem łącznie z Akademii Muzycznej w Krakowie i Uniwersytetu Papieskiego Jana Pawła II w Krakowie odpowiedniej liczby pracowników samodzielnych (8) i niesamodzielnych (4), rozpoczął starania w Ministerstwie Nauki i Szkolnictwa Wyższego o utworzenie dyscypliny funkcjonalne sztuki muzyczne, w których także z muzyki kościelnej można by w przyszłości uzyskiwać stopień doktora.

\section{Formacja stała organistów}

Niezwykle ważna jest formacja organistów pracujących w parafiach - dotyczy to zarówno formacji duchowej, jak i dokształcania w zakresie muzyki i liturgii.

\subsection{Formacja duchowa}

W archidiecezji krakowskiej organizowane są regularnie dni skupienia w listopadzie (w okolicach wspomnienia św. Cecylii) oraz w sobotę przed I niedzielą wielkiego postu. Do niedawna prowadzone były także kilkudniowe rekolekcje, z których w ostatnich latach zrezygnowano, bo organiści w parafiach i tak uczestniczą w co najmniej dwóch tego typu ćwiczeniach duchowych w ciągu roku.

Dużą popularnością wśród organistów archidiecezji krakowskiej cieszy się listopadowy dzień skupienia połączony z dokształcaniem muzyczno-liturgicznym. W sobotę przed I niedzielą wielkiego postu (od 2014 roku) ma natomiast miejsce pielgrzymka muzyków kościelnych do Sanktuarium św. Jana Pawła II. To czas duchowego przygotowania do wielkiego postu i całego roku pracy.

Powraca wciąż myśl o rekolekcjach dla organistów i prawdopodobnie po kilkuletniej przerwie ta inicjatywa zostanie wznowiona w 2018 roku.

Archidiecezjalna Komisja Muzyki Kościelnej opieką duszpasterską obejmuje blisko 200 organistów.

\subsection{Formacja muzyczno-liturgiczna}

We wcześniejszym punkcie zostało już powiedziane na temat udanej próby dokształcania organistów podczas dnia skupienia w listopadzie każdego roku, w którym uczestniczy zwykle ponad 100 organistów. Przez parę lat przy 
Archidiecezjalnej Szkole Muzycznej I i II stopnia prowadzone były też kursy dokształcające dla organistów. Obecnie nie są one prowadzone.

Bardzo ważne dla Archidiecezjalnej Komisji Muzyki Kościelnej jest promowanie właściwego rodzaju i poziomu muzyki kościelnej. Dzieje się to szczególnie w przygotowanych harmonizacjach pieśni i innych śpiewów, które stanowią pomoc dla organistów w ich codziennej pracy. Do 2017 roku ukazały się: Śpiewnik Wawelski (I tom 1999, II tom 2002, III tom 2003, IV tom 2015), Ciebie Boga wysławiamy - odpowiedzi mszalne (2000), Bóg bogaty w Miłosierdzie (2002), Pogrzeb chrześcijański (2001), Nabożeństwa (2007), Śpiewy ku czci św. Jana Pawła II (2014), Śpiewy do św. Jana Kantego (2012), Być dobrym jak chleb - śpiewnik albertyński (2016). Te zawierające harmonizację śpiewniki cieszą się zainteresowaniem organistów w całej Polsce.

Przewodniczący komisji przeprowadza też regularnie cenzury kościelne nowych śpiewów zatwierdzanych do użytku w liturgii w archidiecezji krakowskiej. Często dzieje się to także przy udziale innych członków komisji.

\section{Muzyka wielkich uroczystości liturgicznych w archidiecezji}

Z oczywistych powodów w komitetach organizacyjnych papieskich pielgrzymek zasiadali także członkowie Archidiecezjalnej Komisji Muzyki Kościelnej. Przygotowywali muzykę, a także dyrygowali chórami, byli organistami lub prowadzili wspólny śpiew.

\subsection{Pielgrzymki papieskie $(1997,1999,2002,2006)^{29}$}

\subsubsection{VI pielgrzymka Jana Pawła II w roku 1997}

13 stycznia 1997 roku kard. Franciszek Macharski powołał komitet organizacyjny pielgrzymki papieskiej, w skład którego jako odpowiedzialny za muzykę wszedł ks. Robert Tyrała. W skład komisji muzycznej pielgrzymki powołani zostali Wiesław Delimat, Witold Zalewski, ks. Marian Błaszczyk, Ewa Sterczyńska, Mieczysław Tuleja, Jerzy Kurcz, Adam Korzeniowski ${ }^{30}$. W 1997 roku papież

29 Zob. R. Tyrała, Muzyka podczas papieskich pielgrzymek $w$ archidiecezji krakowskiej (1979-2006), „Pro Musica Sacra” 2016, s. 11-36, https://doi.org/10.15633/pms.1837.

30 Zob. Skład komisji muzycznej pielgrzymki papieża Jana Pawła II do archidiecezji krakowskiej w 1997 roku, Archiwum Archidiecezjalnej Komisji Muzyki Kościelnej, 13 stycznia 1997, bez sygn. 
Jan Paweł II odwiedził Zakopane, gdzie podczas mszy pod Wielką Krokwią 6 czerwca dokonał beatyfikacji m.in. Bernardyny Jabłońskiej ${ }^{31}$. Podczas mszy grały kapele góralskie złożone z przeszło 500 muzyków pod kierownictwem Stanisława Michałczaka i śpiewała schola dzieci góralskich pod dyrekcją Ewy Sterczyńskiej i ks. Mariana Błaszczyka. Śpiewały połączone chóry podhalańskie i grała Orkiestra Reprezentacyjna Straży Granicznej pod dyrekcją kapitana Stanisława Strączka ${ }^{32}$. Organistami podczas uroczystości byli: Piotr Augustyn z parafii Najświętszego Serca Pana Jezusa w Nowym Targu i Andrzej Guziak z parafii Niepokalanego Serca Maryi w Zakopanem na Krzeptówkach. Wszystkie śpiewane przez chóry kompozycje znalazły się w wydanym zeszycie nutowym $^{33} .7$ czerwca w Sanktuarium Wniebowzięcia Najświętszej Maryi Panny w Ludźmierzu papież odmówił z wiernymi różaniec ${ }^{34}$. Podczas tej modlitwy śpiewały chóry: Watra z Raby Wyżnej pod dyrekcją Marii MożdżeńWójcik, Rabiańskie Dzieci z Raby Wyżnej pod kierunkiem tej samej dyrygentki, Wierchy z Zakopanego pod dyrekcją Władysława Kruszewskiego, Echo Gorczańskie z parafii Najświętszego Serca Pana Jezusa w Nowym Targu pod dyrekcją Piotra Augustyna, Gorce z Nowego Targu pod dyrekcją Jana Szostka, parafialny św. Teresy z Rabki pod dyrekcją ks. Romana Sapety, parafialny św. Magdaleny z Rabki pod dyrekcją Stanisława Waisa. Grała także Orkiestra Reprezentacyjna Straży Granicznej pod dyrekcją kapitana Stanisława Strączka ${ }^{35}$. Na organach grał Piotr Augustyn. Na krakowskich Błoniach w dniu 8 czerwca papież kanonizował Jadwigę Królową ${ }^{36}$. Przed liturgią kanonizacji seminarzyści Krakowa odśpiewali napisaną przez Mariana Machurę jutrznię o bł. Jadwidze ${ }^{37}$. Podczas uroczystej liturgii śpiewały chóry: Akademicki Organum pod dyrekcją Bogusława Grzybka, Mariański z parafii Najświętszej Maryi Panny z Lourdes pod dyrekcją Jana Rybarskiego, Wydziału Wychowania Muzycznego Akademii Muzycznej w Krakowie pod dyrekcją Jerzego Kurcza, Wyższego Seminarium Duchownego Archidiecezji Krakowskiej pod dyrekcją

31 Zob. Modlitewnik pielgrzyma. Z Janem Pawtem II w Archidiecezji Krakowskiej, 4-10 czerwca 1997, red. S. Koperek, Kraków 1997, s. 50-52, 55-60.

32 Zob. tamże, s. 110.

33 Zob. Msza święta pontyfikalna o Najświętszym Sercu Pana Jezusa sprawowana przez Ojca Świętego Jana Pawła II, w czasie której dokona beatyfikacji siostry Bernardyny Jabłońskiej i siostry Marii Karłowskiej. Zakopane, 6 czerwca 1997, red. Komisja Muzyczna Pielgrzymki, Kraków 1997.

34 Zob. Modlitewnik pielgrzyma..., dz. cyt., s. 61-63.

35 Zob. tamże, s. 110.

36 Zob. tamże, s. 64-72.

37 Zob. tamże, s. 85-91. 
ks. Roberta Tyrały, Wyższego Seminarium Towarzystwa Salezjańskiego pod dyrekcją Adama Korzeniowskiego, schola Ruchu Światło-Życie pod dyrekcją Elżbiety Chlebdy, Psalmodia Papieskiej Akademii Teologicznej w Krakowie pod dyrekcją Włodzimierza Siedlika, Schola Cantorum Cracoviensis pod dyrekcją Barbary Karpały, Canticum Novum pod dyrekcją Elżbiety Ptak, Dominanta Akademii Ekonomicznej w Krakowie pod dyrekcją Zbigniewa Ciuraby ${ }^{38}$. Wszystkimi chórami dyrygowali Jerzy Kurcz i Adam Korzeniowski, organistami zaś byli Mieczysław Tuleja z kościoła św. Stanisława Kostki w Krakowie-Dębnikach oraz Witold Zalewski, organista katedry na Wawelu. Specjalnie na uroczystość kanonizacji powstała i została wykonana podczas liturgii kompozycja Juliusza Łuciuka Niech będzie Bóg uwielbiony ku czci św. Jadwigi Królowej. Wszystkie śpiewane przez chóry wybrane kompozycje znalazły się w wydanym zeszycie nutowym ${ }^{39} .9$ czerwca 1997 roku papież odprawił poranną mszę w krypcie Leonarda w katedrze na Wawelu, a klerycy Wyższego Seminarium Duchowego Archidiecezji Krakowskiej śpiewali chorał gregoriański. Męski chór katedralny pod dyrekcją Romana Mackiewicza witał papieża wchodzącego do katedry.

\subsubsection{VII pielgrzymka Jana Pawła II w roku 1999}

Kard. Franciszek Macharski dekretem z 7 grudnia 1998 roku powołał komitet organizacyjny pielgrzymki Ojca Świętego do archidiecezji krakowskiej, w skład którego do spraw muzyki wszedł ks. Robert Tyrała. Komisja muzyczna pielgrzymki składała się z następujących członków: Jerzy Kurcz, Jacek Mentel, Włodzimierz Siedlik, Stanisław Krawczyński, Wiesław Delimat, Witold Zalewski, Mieczysław Tuleja, Małgorzata Gawor, Adam Kocyk, Piotr Pałka, Marek Seyfried ${ }^{40}$. Papież Jan Paweł II przybył do archidiecezji krakowskiej w 1999 roku. 15 czerwca na krakowskich Błoniach niestety nie przewodniczył sam liturgii, był bowiem chory, w jego imieniu mszę celebrował kard. Angelo Sodano, sekretarz stanu Stolicy Apostolskiej. Była to liturgia z okazji 1000-lecia diecezji krakowskiej. W specjalnie przygotowanym nutowym

38 Zob. tamże, s. 110.

39 Zob. Kanonizacja Błogosławionej Jadwigi Królowej. Błonia Krakowskie, 8 czerwca 1997 roku, red. Komisja Muzyczna Pielgrzymki, Kraków 1997.

40 Zob. Skład komisji muzycznej pielgrzymki papieża Jana Pawła II do archidiecezji krakowskiej w 1999 roku, Archiwum Kurii Metropolitalnej w Krakowie, 7 grudnia 1998, bez sygn. 
zeszycie umieszczone zostały wszystkie śpiewy chórów ${ }^{41}$. Organistami podczas tej liturgii byli Mieczysław Tuleja z kościoła św. Stanisława Kostki w Krakowie-Dębnikach, Wiesław Delimat z kościoła św. Marka w Krakowie i Witold Zalewski z katedry na Wawelu. Podczas liturgii grała orkiestra Huty im. Tadeusza Sendzimira pod dyrekcją Marka Seyfrieda ${ }^{42}$. Śpiewane były także utwory przygotowane przez scholę akademicką pod dyrekcją Piotra Pałki i Adama Kocyka oraz Małgorzaty Gawor ${ }^{43} .17$ czerwca 1999 roku przy ołtarzu św. Stanisława w katedrze na Wawelu Ojciec Święty odprawił liturgię Eucharystii. Podczas liturgii śpiewał chór męski chór katedralny, na organach grał Witold Zalewski.

\subsubsection{VII pielgrzymka Jana Pawła II w roku 2002}

Kard. Franciszek Macharski 19 marca 2002 roku powołał komitet pielgrzymki papieża w archidiecezji krakowskiej, w skład której jako odpowiedzialny za muzykę wszedł ks. Robert Tyrała ${ }^{44}$. Komisję muzyczną pielgrzymki tworzyli Wiesław Delimat, Witold Zalewski, Mieczysław Tuleja, s. Katarzyna Kozubek, s. Ligia Bender, Bogusław Grzybek, Jan Rybarski ${ }^{45}$. Jan Paweł II z ostatnią swoją pielgrzymką do archidiecezji krakowskiej przybył w 2002 roku. 17 sierpnia dokonał dedykacji kościoła Bożego Miłosierdzia w Krakowie-Łagiewnikach i zawierzył świat Miłosierdziu Bożemu. Następnie 18 sierpnia 2002 roku odprawił uroczystą Eucharystię na krakowskich Błoniach. 19 sierpnia odprawił ostatnią swoją mszę w Polsce przy obrazie Matki Bożej Kalwaryjskiej. Podczas uroczystej liturgii w kościele w Łagiewnikach śpiewał Chór Mariański z parafii Najświętszej Maryi Panny z Lourdes w Krakowie pod dyrekcją Jana Rybarskiego oraz międzyzakonna schola sióstr, którą zebrały na tę okazję i dyrygowały podczas uroczystości siostry Katarzyna Kozubek, służebniczka starowiejska, oraz sercanka Ligia Bender. Dla potrzeb scholi sióstr i chóru

41 Zob. Msza święta sprawowana przez Ojca Świętego Jana Pawła II w Milenium Diecezji Krakowskiej. Błonia Krakowskie, 15 czerwca 1999, red. Komisja Muzyczna Pielgrzymki, Kraków 1999.

42 Zob. Pielgrzymka Jana Pawła II w Krakowie w 1999 roku, Archiwum Kurii Metropolitalnej w Krakowie, bez sygn.

43 Zebrane śpiewy zostały także wykorzystywane w późniejszych spotkaniach.

44 Zob. kard. Franciszek Macharski, Dekret powołujący komitet organizacyjny pielgrzymki Ojca Świętego Jana Pawła II do archidiecezji krakowskiej nr 727/2002, 19 marca 2002; Pielgrzymka Jana Pawła II do Krakowa w 2002 roku, Archiwum Kurii Metropolitalnej w Krakowie, bez sygn.

45 Zob. Skład komisji muzycznej pielgrzymki papieża Jana Pawła II do Archidiecezji krakowskiej w 2002 roku, Archiwum Kurii Metropolitalnej w Krakowie, 19 marca 2002, bez sygn. 
został przygotowany zeszyt nutowy ${ }^{46} .18$ sierpnia Ojciec Święty odprawił uroczystą liturgię na krakowskich Błoniach. Z tej okazji został przygotowany dla chóru zeszyt nutowy ${ }^{47}$. Podczas uroczystej liturgii śpiewały połączone chóry z Krakowa, schola młodzieżowa. Dyrygentami byli Włodzimierz Siedlik i Wiesław Delimat, organistami Wiesław Delimat, Witold Zalewski i Krzysztof Michałek. 19 sierpnia 2002 roku papież Jan Paweł II odwiedził kalwaryjskie sanktuarium, przybył tam z okazji 400-lecia jego istnienia. Podczas liturgii śpiewano tradycyjne pieśni kalwaryjskie $\mathrm{z}$ wiernymi ${ }^{48}$.

\subsubsection{Pielgrzymka Benedykta XVI w roku 2006}

Ojciec Święty Benedykt XVI przybył do Krakowa w 2006 roku. 27 maja miało miejsce spotkanie z młodzieżą z całej Polski, zaś 28 maja odprawił uroczystą mszę na krakowskich Błoniach. Specjalnie na ogólnopolskie spotkanie z młodymi została utworzona schola akademicka studentów Krakowa. Przygotowano śpiewnik chóralny ${ }^{49}$. Chórem i orkiestrą młodych dyrygował Piotr Pałka. Śpiewali wszyscy młodzi obecni na spotkaniu, korzystając ze specjalnie dla nich przygotowanych śpiewników ${ }^{50} .28$ maja 2006 roku, w dzień Wniebowstąpienia Pańskiego, Ojciec Święty odprawił uroczystą Eucharystię na krakowskich Błoniach. Zespół muzyczny tworzyły krakowskie chóry oraz studenci Akademii Muzycznej w Krakowie. Grała także orkiestra symfoniczna Akademii Muzycznej w Krakowie. Dyrygentami byli Stanisław Krawczyński i Wiesław Delimat, za organami zasiadali Witold Zalewski i Krzysztof Michałek. Dla chórów został przygotowany specjalny zeszyt nutowy ${ }^{51}$. Papież odprawił również mszę łacińską w kaplicy metropolity krakowskiego. Miała to być cicha msza, jednak podczas liturgii śpiewała schola gregoriańska Wyższego Seminarium Duchownego Archidiecezji Krakowskiej pod dyrekcją ks. Roberta

46 Zob. Bóg bogaty w miłosierdzie. Pielgrzymka Jana Pawła II do Polski 2002, red. Komisja Muzyczna Pielgrzymki, Kraków 2002.

47 Zob. Bóg bogaty w miłosierdzie. Eucharystia z Janem Pawłem II. Błonia Krakowskie, 18 sierpnia 2002 roku. Zeszyt nutowy, Kraków 2002.

48 Zob. Jubileusz 400-lecia Sanktuarium Kalwaryjskiego 1602-2002. Teksty liturgiczne mszy świętej o Najświętszej Maryi Pannie Kalwaryjskiej. 19 sierpnia 2002. II Pielgrzymka Ojca Świętego Jana Pawła II do Kalwarii Zebrzydowskiej, red. E. Lenart, Kalwaria Zebrzydowska 2002, s. 7-31.

49 Zob. Ogólnopolskie Spotkanie Młodych z papieżem Benedyktem XVI, Kraków, Błonia 27 maja 2006 r., red. Komisja Muzyczna Pielgrzymki, Kraków 2006.

50 Zob. Ogólnopolskie Spotkanie Młodych z Ojcem Świętym Benedyktem XVI „Trwajcie mocni w wierze”, krakowskie Błonia 27 maja 2006 r. Śpiewnik, red. P. Iwanek, Kraków 2006.

51 Zob. Eucharystia pod przewodnictwem Ojca Świętego Benedykta XVI. Kraków, Błonia, 28 maja 2006 r., red. Komisja Muzyczna Pielgrzymki, Kraków 2006. 
Tyrały. Na specjalnie sprowadzonym na tę uroczystość pozytywie organowym ${ }^{52}$ grali Witold Zalewski i Wiesław Delimat ${ }^{53}$. Pozytyw ten pozostał w kaplicy biskupów krakowskich jako świadek tamtej uroczystości.

\section{2. Światowy Dzień Młodzieży (2016) ${ }^{54}$}

Jesienią 2015 roku miały miejsce pierwsze spotkania zespołu ds. muzyki Światowych Dni Młodzieży, który składał się z Wiesława Delimata, o. Dawida Kusza OP, Piotra Pałki (tylko na początku prac), Janusza Wierzgacza (po rezygnacji Piotra Pałki), Bartłomieja Karwańskiego, Adama Sztaby, Marka Pawełka, ks. Łukasza Michalczewskiego, Łukasza Jarockiego (który koordynował całe przedsięwzięcie muzyczne z ramienia biura Światowych Dni Młodzieży) oraz prowadzącego prace tego zespołu ks. Roberta Tyrały. Do zespołu dołączyli później Krzysztof Michałek (grał jako II organista na uroczystościach), Gabriela Gąsior i o. Lech Dorobczyński OFM (te dwie ostatnie osoby zwłaszcza w sprawach koncertu po czuwaniu z papieżem w Brzegach). Ks. Robert Tyrała przyjął odpowiedzialność za obie msze (wtorek i niedziela), Wiesław Delimat - za drogę krzyżową, a Adam Sztaba - za uroczystości w czwartek i sobotę. Muzyka, która ostatecznie po wielu dyskusjach została wybrana na wydarzenia centralne, a więc mszę powitania pielgrzymów (wtorek 26 lipca) ${ }^{55}$, powitanie papieża (czwartek 28 lipca) ${ }^{56}$, czuwanie (sobota 30 lipca ${ }^{57}$ oraz mszę posłania (niedziela 31 lipca) ${ }^{58}$, składała się z tzw. repertuaru Światowych Dni Młodzieży, tradycji dominikańskiej, doświadczenia muzycznego spotkań młodych z Lednicy, Ruchu Światło-Życie, tradycji Pueri Cantores oraz kilku

52 Pozytyw organowy został skonstruowany przez firmę Kaczmarczyk z Zabrza. Instrument ma 4 głosy. Pozostał od tego czasu w kaplicy biskupa krakowskiego i służy liturgii.

53 Słynne stało się powiedzenie Witolda Zalewskiego na antenie Radia Plus: „był jeden papież i dwóch organistów”.

54 Zob. R. Tyrała, Muzyka Światowych Dni Młodzieży Częstochowa 1991 i Kraków 2016, [w:] Et super hanc petram. Księga pamiątkowa z okazji 75-lecia urodzin Księdza Profesora Kazimierza Szymonika, pod red. M. Sławeckiego Warszawa 2017, s. 225-238.

55 Zob. Program muzyczny Mszy otwarcia, 26 lipca 2016 roku, Kraków-Błonia, Archiwum Kurii Metropolitalnej w Krakowie, ŚDM Kraków 2016, zeszyt II.

56 Zob. Program muzyczny Powitania papieża, 28 lipca 2016 roku, Kraków-Błonia, Archiwum Kurii Metropolitalnej w Krakowie, ŚDM Kraków 2016, zeszyt II.

57 Zob. Program muzyczny Czuwania z papieżem, 30 lipca 2016 roku, Wieliczka-Brzegi, Archiwum Kurii Metropolitalnej w Krakowie, ŚDM Kraków 2016, zeszyt II.

58 Zob. Program muzyczny Mszy posłania, 31 lipca 2016 roku, Wieliczka-Brzegi, Archiwum Kurii Metropolitalnej w Krakowie, ŚDM Kraków 2016, zeszyt II. 
nowości. Można powiedzieć, że były to więc utwory stare i znane, ale w nowej aranżacji i opracowaniu. Zawdzięczamy to Adamowi Sztabie, o. Dawidowi Kuszowi OP, Markowi Pawełkowi i Januszowi Wierzgaczowi. Koncepcję muzyczną związaną z drogą krzyżową na piątek 29 lipca59 stworzył Wiesław Delimat. Podczas sobotniego czuwania siostry zakonne Krakowa wykonały koronkę do Bożego Miłosierdzia. Melodie tej koronki na kanonizację s. Faustyny Kowalskiej przygotował w 5 językach Stefan Stuligrosz w marcu 2000 roku. Po przesłuchaniach indywidualnych, które miały miejsce od października 2015 do marca 2016 roku, wyłoniony został 320-osobowy chór i 80-osobowa orkiestra ${ }^{60}$. Chór Światowych Dni Młodzieży wystąpił po raz pierwszy 8 maja 2016 roku podczas uroczystości ku czci św. Stanisława BM w Krakowie Na Skałce. Msza z udziałem episkopatu Polski była więc premierą wielu utworów, które później zabrzmiały na wydarzeniach Światowych Dni Młodzieży w Krakowie, w tym Mszy Jana Pawła II napisanej na Światowe Dni Młodzieży przez Henryka Jana Botora. Kompozytor ukończył ją 2 kwietnia 2016 roku w XI rocznicę przejścia Jana Pawła II do domu Ojca.

\section{Inne formy działalności}

Inne inicjatywy członków Archidiecezjalnej Komisji Muzyki Kościelnej to między innymi wydawany w latach 1998-2010 i wznowiony w 2017 roku biuletyn „Organista”, który stanowi dodatek do miesięcznika „Biuletyn Duszpasterski” i jest skierowany do wszystkich organistów archidiecezji, oraz publikowane od 2004 roku przez Uniwersytet Papieski Jana Pawła II w Krakowie recenzowane czasopismo naukowe „Pro Musica Sacra” (od 2012 roku w wersji online w otwartym dostępie: http://czasopisma.upjp2.edu.pl/ promusicasacra). W 2004 roku organizowany był w Krakowie I Ogólnopolski Kongres Muzyki Liturgicznej ${ }^{61}$. Od 2005 roku w listopadzie we wspomnienie św. Cecylii organizowane są Dni Muzyki Kościelnej w Archidiecezji

59 Zob. Program muzyczny drogi krzyżowej, 29 lipca 2016 roku, Kraków-Błonia, Archiwum Kurii Metropolitalnej w Krakowie, ŚDM Kraków 2016, zeszyt II.

60 Zob. Ł. Jarocki, Raport muzyka ŚDM Kraków 2016, Archiwum Kurii Metropolitalnej w Krakowie, ŚDM Kraków 2016, zeszyt II.

61 Zob. R. Tyrała, I Ogólnopolski Kongres Muzyki Liturgicznej Musicam Sacram Promovere na tle wcześniejszych inicjatyw odnowy muzyki kościelnej w Polsce, „Ruch Biblijny i Liturgiczny” 58 (2005) nr 3, s. 218-232, https://doi.org/10.21906/rbl.598. 
Krakowskiej (liturgie, koncerty, sympozja ogólnopolskie i międzynarodowe, kursy mistrzowskie). W latach 2005-2011 ukazywały się listy metropolity krakowskiego kard. Stanisława Dziwisza do muzyków archidiecezji ${ }^{62}$. Od 2008 roku w listopadzie komisja organizuje Konkurs Młodych Organistów. W 2011 roku komisja przygotowywała muzykę na II Światowy Kongres Bożego Miłosierdzia w Krakowie. W 2015 roku członkowie komisji byli zaangażowani w przeprowadzenie i nadanie papieżowi emerytowi Benedyktowi XVI doktoratów honoris causa Akademii Muzycznej w Krakowie i Uniwersytetu Papieskiego Jana Pawła II w Krakowie ${ }^{63}$. W 2015 roku ukazało się kolejne wydanie Śpiewnika Siedleckiego, którego redaktorem jest jeden z członków komisji. Cyklicznie ukazują się wydawnictwa audio i wideo (są to dzieła muzyków kościelnych Krakowa). Komisja opiniuje też muzykę liturgiczną wykonywaną podczas transmisji telewizyjnych z Sanktuarium Bożego Miłosierdzia w Krakowie-Łagiewnikach (piątek w TVP Kraków, niedziela w TVP 1). Powstają schole gregoriańskie, jak np. Flores Rosarum. Członkowie komisji prowadzą badania naukowe chorału gregoriańskiego, a od roku akademickiego 2016/2017 prowadzone są Podyplomowe Studia z Monodii Liturgicznej na Uniwersytecie Papieskim Jana Pawła II w Krakowie. Członkowie komisji są organizatorami Festiwali Muzyki Organowej (Zakopane, Skawina), Mariackiego Festiwalu Organowego w Krakowie oraz Muzycznych Spotkań na Wzgórzach Krzesławickich w Krakowie-Nowej Hucie.

\section{Zakończenie}

Największy wpływ na muzykę kościelną w archidiecezji krakowskiej w latach 1997-2017 miała działalność Archidiecezjalnej Komisji Muzyki Kościelnej, działalność edukacyjna organizowana lub inicjowana przez diecezję, a także wielkie wydarzenia liturgiczne z udziałem trzech papieży. Archidiecezjalna Komisja Muzyki Kościelnej w omawianym okresie uczestniczyła w przygotowaniu dwóch regulaminów: dotyczącego pracy organistów, którego najnowsza wersja pochodzi z 2011 roku, a jego zalecenia ciągle wprowadzane są w życie, oraz regulaminu dotyczącego organów piszczałkowych z 2007 roku. Komisja

62 Zob. http://www.diecezja.pl/wierni/muzyka-koscielna.html (19.02.2017).

63 Zob. R. Tyrała, Benedykt XVI doktorem honoris causa Akademii Muzycznej i Uniwersytetu Papieskiego Jana Pawła II w Krakowie, „Pro Musica Sacra” 13 (2015), s. 9-43, https://doi.org/10.15633/pms.1111. 
patronowała również konkursom dla ponad 100 chórów i schól parafialnych działających w archidiecezji. W omawianym dwudziestoleciu w archidiecezji krakowskiej powstały instytucje kształcące organistów w trzystopniowym modelu kształcenia: szkoły muzyczne I i II stopnia mające uprawnienia szkół publicznych oraz międzyuczelniany instytut kształcący organistów na studiach licencjackich i uzupełniających magisterskich. Archidiecezjalna Komisja Muzyki Kościelnej zajmowała się także kształceniem ustawicznym organistów podczas rekolekcji i dni skupienia oraz warsztatów i kursów. Pielgrzymki papieskie w latach 1997, 1999, 2002 (Jan Paweł II), 2006 (Benedykt XVI) i Światowe Dni Młodzieży 20016 z udziałem papieża Franciszka były nie tylko wyzwaniem organizacyjnym, ale także okazją do prezentacji tradycyjnych i nowych kompozycji wykonywanych w archidiecezji.

\section{Abstrakt}

\section{Muzyka kościelna w archidiecezji krakowskiej w latach 1997-2017}

Artykuł omawia instytucje i wydarzenia, które w latach 1997-2017 miały decydujący wpływ na muzykę kościelną w archidiecezji krakowskiej. Omówiona została działalność Archidiecezjalnej Komisji Muzyki Kościelnej, Archidiecezjalnej Szkoły Muzycznej I i II stopnia, Międzyuczelnianego Instytutu Muzyki Kościelnej, a także wielkie wydarzenia liturgiczne z udziałem trzech papieży.

Słowa kluczowe: archidiecezja krakowska; muzyka kościelna; Jan Paweł II, Benedykt XVI, papież Franciszek

\section{Abstract}

\section{Church Music in the Archdiocese of Krakow in 1997-2017}

This article deals with the institutions and events that in 1997-2017 had a decisive impact on Church music in the Archdiocese of Krakow. It discusses the activity of the Archdiocesan Church Music Committee, the Archdiocesan Music Schools of the First and Second Level, the Interuniversity Institute of Church Music, and major liturgical events in which three popes participated.

Keywords: Archdiocese of Cracow; church music; John Paul II, Benedict XVI, Pope Francis

\section{References}

Archidiecezja krakowska - wierni - muzyka kościelna. (n.d.). Retrieved January 16, 2018, from http://diecezja. $\mathrm{pl} /$ wierni/muzyka-koscielna.html

Bóg bogaty w miłosierdzie. Eucharystia z Janem Pawtem II. Błonia Krakowskie, 18 sierpnia 2002 roku. Zeszyt nutowy. (2002). Kraków. 
Delimat, W. (2000). Archidiecezjalna Szkoła Organistowska. Organista, (15), 2-3.

Dziwisz, S. (2006, April 3). Dekret dotyczący Archidiecezjalnej Szkoły Muzycznej I i II stopnia. (NDz. 625/2006). Kancelaria Metropolity Krakowskiego.

Dziwisz, S. (2007, August 7). List pasterski do archidiecezji krakowskiej.

Iwanek, P. (Ed.). (2006). Ogólnopolskie Spotkanie Młodych z Ojcem Świętym Benedyktem XVI „Trwajcie mocni w wierze”, krakowskie Błonia 27 maja 2006 r. Śpiewnik. Kraków: Wydawnictwo św. Stanisława BM Archidiecezji Krakowskiej.

Jarocki, Ł. (n.d.). Raport muzyka ŚDM Kraków 2016. (ŚDM Kraków 2016, zeszyt II). Archiwum Kurii Metropolitalnej w Krakowie.

Komisja Muzyczna Pielgrzymki (Ed.). (1997a). Kanonizacja Błogosławionej Jadwigi Królowej. Błonia Krakowskie, 8 czerwca 1997 roku. Kraków.

Komisja Muzyczna Pielgrzymki (Ed.). (1997b). Msza święta pontyfikalna o Najświętszym Sercu Pana Jezusa sprawowana przez Ojca Świętego Jana Pawła II, w czasie której dokona beatyfikacji siostry Bernardyny Jabłońskiej i siostry Marii Karłowskiej. Zakopane, 6 czerwca 1997. Kraków.

Komisja Muzyczna Pielgrzymki (Ed.). (1999). Msza święta sprawowana przez Ojca Świętego Jana Pawła II w Milenium Diecezji Krakowskiej. Błonia Krakowskie, 15 czerwca 1999. Kraków.

Komisja Muzyczna Pielgrzymki (Ed.). (2002). Bóg bogaty w miłosierdzie. Pielgrzymka Jana Pawła II do Polski 2002. Kraków.

Komisja Muzyczna Pielgrzymki (Ed.). (2006a). Eucharystia pod przewodnictwem Ojca Świętego Benedykta XVI. Kraków, Błonia, 28 maja 2006 r. Kraków: Wydawnictwo św. Stanisława BM Archidiecezji Krakowskiej.

Komisja Muzyczna Pielgrzymki (Ed.). (2006b). Ogólnopolskie Spotkanie Młodych z papieżem Benedyktem XVI, Kraków, Błonia 27 maja 2006 r. Kraków: Wydawnictwo św. Stanisława BM Archidiecezji Krakowskiej.

Koperek, S., Bukowski, K., Gryz, K., Machniak, J., \& Szczepaniec, S. (Eds.). (1997). Modlitewnik pielgrzyma. ZJanem Pawtem II w Archidiecezji Krakowskiej, 4-10 czerwca 1997. Kraków: Wydawnictwo św. Stanisława BM Archidiecezji Krakowskiej.

Lenart, E. (2002). Jubileusz 400-lecia Sanktuarium Kalwaryjskiego 1602-2002. Teksty liturgiczne mszy świętej o Najświętszej Maryi Pannie Kalwaryjskiej. 19 sierpnia 2002. II Pielgrzymka Ojca Świętego Jana Pawła II do Kalwarii Zebrzydowskiej. Kalwaria Zebrzydowska.

Macharski, F. (1997, January 10). Dekret ustanawiający Archidiecezjalne Studium Organistowskie. (NDz. 2885/1997). Archiwum Kurii Metropolitalnej w Krakowie.

Macharski, F. (1998, July 30). Dekret ustanawiający Archidiecezjalną Szkołę Organistowską. (NDz. 2096/1998). Archiwum Kurii Metropolitalnej w Krakowie.

Macharski, F. (2002, March 19). Dekret powołujący komitet organizacyjny pielgrzymki Ojca Świętego Jana Pawła II do archidiecezji krakowskiej. (727/2002). Archiwum Kurii Metropolitalnej w Krakowie.

Minister Kultury i Dziedzictwa Narodowego. (2007, January 31). Decyzja w sprawie nadania uprawnień szkoły publicznej dla Archidiecezjalnej Szkoły Muzycznej I stopnia w Krakowie. (DSA II 077/383/2007/IS).

Minister Nauki i Szkolnictwa Wyższego. (2008a, January 2). Decyzja nadająca Wydziałowi Historii Kościoła Papieskiej Akademii Teologicznej w Krakowie uprawnienia do prowadzenia studiów na kierunku „muzyka kościelna”. (DSW-1-03-4002/14/08).

Minister Nauki i Szkolnictwa Wyższego. (2008b, January 2). Decyzja nadająca Wydziałowi Twórczości, Interpretacji i Edukacji Muzycznej Akademii Muzycznej w Krakowie uprawnienia do prowadzenia studiów na kierunku „muzyka kościelna”. (DSW-1-03-4002/15/08).

Papieska Akademia Teologiczna w Krakowie Wydział Historii Kościoła. (2001). Informator na rok akademicki 2001/2002. Kraków.

Pielgrzymka Jana Pawła II do Krakowa w 2002 roku. (n.d.). Archiwum Kurii Metropolitalnej w Krakowie. Pielgrzymka Jana Pawła II w Krakowie w 1999 roku. (n.d.). Archiwum Kurii Metropolitalnej w Krakowie. 
Podsekretarz Stanu w Ministerstwie Kultury i Sztuki. (1999, September 16). Decyzja nadania Archidiecezjalnej Szkole Organistowskiej uprawnień szkoły publicznej. (DSA.I.7755-ps21/A/99).

Program muzyczny Czuwania z papieżem, 30 lipca 2016 roku, Wieliczka-Brzegi. (n.d.). (ŚDM Kraków 2016, zeszyt II). Archiwum Kurii Metropolitalnej w Krakowie.

Program muzyczny drogi krzyżowej, 29 lipca 2016 roku, Kraków-Błonia. (n.d.). (ŚDM Kraków 2016, zeszyt II). Archiwum Kurii Metropolitalnej w Krakowie.

Program muzyczny Mszy otwarcia, 26 lipca 2016 roku, Kraków-Błonia. (n.d.). (ŚDM Kraków 2016, zeszyt II). Archiwum Kurii Metropolitalnej w Krakowie.

Program muzyczny Mszy posłania, 31 lipca 2016 roku, Wieliczka-Brzegi. (n.d.). (ŚDM Kraków 2016, zeszyt II). Archiwum Kurii Metropolitalnej w Krakowie.

Program muzyczny Powitania papieża, 28 lipca 2016 roku, Kraków-Błonia. (n.d.). (ŚDM Kraków 2016, zeszyt II). Archiwum Kurii Metropolitalnej w Krakowie.

Regulamin budowy organów, przeprowadzania remontów i renowacji oraz sprowadzania używanych organów w archidiecezji krakowskiej. (2007). Kraków: Wydawnictwo św. Stanisława BM Archidiecezji Krakowskiej.

Regulamin organistów Archidiecezji Krakowskiej. (2000). Kraków: Wydawnictwo św. Stanisława BM Archidiecezji Krakowskiej.

Regulamin organistów Archidiecezji Krakowskiej. (2005). Kraków: Wydawnictwo św. Stanisława BM Archidiecezji Krakowskiej.

Regulamin organistów Archidiecezji Krakowskiej. (2011). Kraków.

Sandera, Ł. (2015). Archidiecezjalna Szkoła Muzyczna imienia ks. kardynała Franciszka Macharskiego w Krakowie - historia i teraźniejszość. Akademia Muzyczna w Krakowie, Kraków.

Skład komisji muzycznej pielgrzymki papieża Jana Pawła II do archidiecezji krakowskiej w 1997 roku. (1997, January 13). Archiwum Kurii Metropolitalnej w Krakowie.

Skład komisji muzycznej pielgrzymki papieża Jana Pawła II do archidiecezji krakowskiej w 1999 roku. (1998, July 12). Archiwum Kurii Metropolitalnej w Krakowie.

Skład komisji muzycznej pielgrzymki papieża Jana Pawła II do Archidiecezji krakowskiej w 2002 roku. (2002, March 19). Archiwum Kurii Metropolitalnej w Krakowie.

Tyrała, R. (2005). I Ogólnopolski Kongres Muzyki Liturgicznej Musicam Sacram Promovere na tle wcześniejszych inicjatyw odnowy muzyki kościelnej w Polsce. Ruch Biblijny i Liturgiczny, 58(3), 218-232. https://doi. org/10.21906/rbl.598

Tyrała, R. (2009a). Historia kształcenia w zakresie muzyki kościelnej w archidiecezji krakowskiej po reformie soborowej. Ateneum Kaptańskie, 153(1-2), 38-54.

Tyrała, R. (2009b). Kierunek „muzyka kościelna” nową formą kształcenia muzycznego w Polsce. Muzyk Kościelny, (1), 35-41.

Tyrała, R. (2012). Regulamin organistów w archidiecezji krakowskiej. Pro Musica Sacra, 10(0), 9-20. https://doi. org/10.15633/pms.336

Tyrała, R. (2015). Benedykt XVI doktorem honoris causa Akademii Muzycznej i Uniwersytetu Papieskiego Jana Pawła II w Krakowie. Pro Musica Sacra, 13(0), 9-43. https://doi.org/10.15633/pms.1111

Tyrała, R. (2016a). Muzyka podczas papieskich pielgrzymek w archidiecezji krakowskiej (1979-2006). Pro Musica Sacra, 14(0), 11-36. https://doi.org/10.15633/pms.1837

Tyrała, R. (2016b). Regulamin budowy, remontu i sprowadzania z zagranicy instrumentów w archidiecezji krakowskiej z 2007 r. Musica Ecclesiastica, 11, 77-83.

Tyrała, R. (2017). Muzyka Światowych Dni Młodzieży Częstochowa 1991 i Kraków 2016. In M. Sławecki (Ed.), Et super hanc petram: księga pamiątkowa z okazji 75-lecia urodzin Księdza Profesora Kazimierza Szymonika (pp. 225-238). Warszawa: Uniwersytet Muzyczny Fryderyka Chopina. 